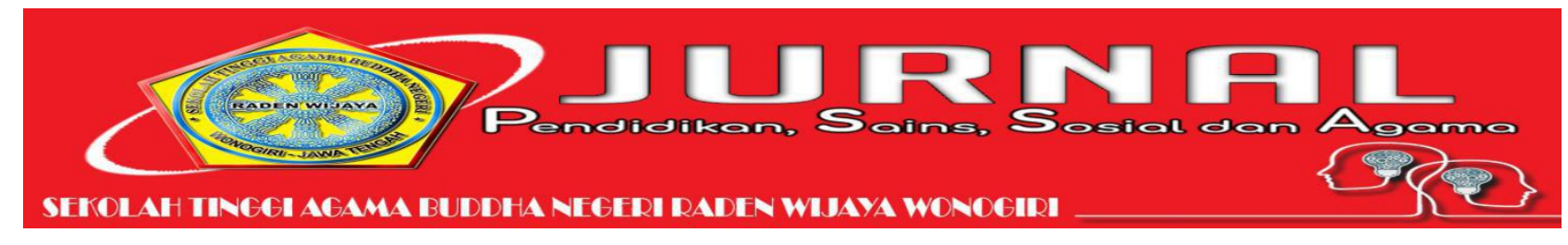

\title{
MANAJEMEN STRATEGI DALAM MENINGKATKAN MUTU PENDIDIKAN DHAMMASEKHA SADDHAPALA JAYA KABUPATEN TEMANGGUNG
}

\author{
Metta Puspita Dewi \\ Sekolah Tinggi Agama Buddha Negeri Raden Wijaya Wonogiri \\ mettastabnrw@gmail.com
}

\begin{abstract}
ABSTRAK
Manajemen strategi Dhammasekha diawali dengan 1) formulasi strategi yakni dengan mengidentifikasi kekuatan terdapat pada profesionalitas guru,unggul di bidang seni dan budaya, sarana dan prasarana, citra positif. Kelemahan Dhammasekha meliputi sumber dana, belum terdapat kurikulum paten, lokasi kurang stetegis, belum memiliki ijin operasional serta motivasi SDM masih lemah. Dhammasekha memiliki peluang menjadi lembaga pendidikan pilihan umat Buddha karena dukungan 16 Vihara namun memiliki ancaman persaingan dengan lembaga pendidikan lain yang lebih aktif dan kreatif di dekat lokasi Dhammasekha. 2) Implementasi strategi dilakukan dengan membuat program atau kebijakan, membentuk struktur organsiasi sesuai dengan komptensi dan memotivasi. 3) Evaluasi strategi dilakukan ketua secara rutin guna mengukur performa Dhammasekha dan mengambil langkah korektif melalui pelibatan guru stakeholder, tokoh dan wali murid agar mendukung peningkatan mutu lembaga. Dhammasekha selalu berfokus pada kepuasan umat, membangun komitmen, kerjasama timdan perbaikan secara terus menerus.
\end{abstract}

Kata kunci: Manajemen Strategi, Mutu, Dhammasekha

\begin{abstract}
Dhammasekha strategy management begins with 1) strategy of formulation which is identify the power been found in teacher professionalism, capabillity in the arts and culture, facilities and infrastructure, positive image. Weaknesses of Dhammasekha include funding sources, There is no patent curriculum, location are not strategic, doesn't have an operational permit and the motivation of human resource still weak. Dhammasekha has the opportunity to be preferred educational institute for Buddhists because support of 16 Buddhists temple but has the threat of competition with others as a educational institution which is more active and creative close by Dhammasekha location. 2) Strategic of implementation has been done by creating programs or policies, forming organization structure according with competencies and motivating 3 ) evaluate strategic has been done regullary by the chairman to measure Dhammasekha performance and take an corrective action through involve by stakeholder teachers,leaders and representative of students to support the improvement quality of the institution. Dhammasekha focused on member of buddhism to get theirs satisfication, build up commitment, and continous teamwork improvement.
\end{abstract}

Keywords: Strategy Management, Quality, Dhammasekha

\section{LATAR BELAKANG}

Dunia pendidikan pada umumnya sedang menghadapi berbagai tantangan di era globalisasi. Beberapa tantangan pendidikan antara lain globalisasi di bidang budaya, etika dan moral sebagai akibat dari kemajuan teknologi di bidang transportasi dan informasi. Dengan diberlakukannya globalisasi dan perdagangan Jurnal Pendidikan, Sains Sosial dan Agama Volume VI Nomor 1 Juli 2020 Asosiasi Dosen \& Unit Penelitian dan Pengabdian Masyarakat bebas berarti persaingan dalam ketahanan semakin ketat. Berdasarkan hasil survey internasional dalam penelitian Rusniati (2015:109) menunjukkan bahwa mutu pendidikan di Indonesia masih rendah atau bahkan selalu ditempatkan dalam posisi juru kunci jika dibandingkan dengan negara-negara tetangga 
Manajemen strategik menurut Akdon (2007:5) adalah suatu seni atau keterampilan, teknik, dan ilmu merumuskan, mengimplementasikan, dan mengevaluasi serta mengawasi berbagai keputusan fungsional organisasi yang selalu dipengaruhi oleh lingkungan internal dan eksternal, yang senantiasa berubah sehigga memberikan kemampuan kepada organisasi untuk mencapai tujuan sesuai dengan yang diharapkan. Pella (2016:21) menyatakan bahwa manajemen strategik memungkinkan organisasi beranjak dari posisi saat ini mencapai posisi yang diimpikan di masa depan. Sehingga dapat dipahami bahwa dalam merumuskan strategik perlu meninjau faktor internal dan eksternal organisasi.

Sumber daya manusia berkorelasi positif dengan kualitas pendidikan. Usaha sadar dan terencana untuk mewujudkan iklim pembelajaran serta proses pembelajar agar para peserta didik secara optimal dapat memperdalam potensi diri yang dimiliki merupakan peran pendidikan. Berbagai upaya telah dilakukan oleh berbagai pihak yang peduli terhadap pendidikan melalui berbagai metode untuk meningkatkan kualitas pendidikan. Upaya yang telah dilakukan tidak berhenti begitu saja melainkan terus ditingkatkan melalui suatu perubahan dari waktu ke waktu. Pada intinya pendidikan harus memiliki peran dalam pengembangan sumber daya manusia yang baik, bijaksana, berkarakter, berketerampilan dan menjadi warga negara yang demokratis dan bertanggung jawab.

Pendidikan agama Buddha masih tertinggal dibandingkan dengan pendidikan agama lain yang berkembang sangat pesat. Ketertinggalan ini dapat dilihat dari segi kualitas dan kuantitas. Jika pendidikan berbasis agama lain sudah pada taraf pendidikan formal, agama Buddha masih pada pendidikan non formal. Pada pendidikan Buddhis non formal sekalipun, jumlahnya masih sangat terbatas. Bahkan di Kabupaten Temanggung sebagai daerah yang padat umat Buddha hanya tersedia dua Dhammasekha.

Dhamma Sekha berdasarkan Keputusan Direktur Jenderal Bimbingan Masyarakat Buddha Nomor 465 Tahun 2011 berarti pendidikan non formal yang diselenggarakan oleh Yayasan Pendidikan dan Keagamaan Buddha. Dhamma Sekha bertujuan untuk pendidikan keterampilan hidup yang berlandasakan pada prisip-prinsip ajaran Buddha. Dhammasekha merupakan lembaga atau wahana persatuan dan kesatuan umat Buddha tanpa memihak tradisi tertentu. Manfaat Dhammasekha bagi umat Buddha yaitu dapat mengembangkan sumber daya manusia
Buddhis melalui kegiatan-kegiatan yang kelak dapat diterapkan sebagai bekal dalam kehidupan sehari-hari di tengah masyarakat yang multikultural.

Dhammasekha Saddhapala merupakan salah satu dari dua Dhammasekha yang terletak di Temanggung. Salah satu kegiatan pendidikan yang sudah berjalan di Dhammasekha Saddhapala adalah kelompok belajar, Taman Kanak Kanak, dan bimbingan belajar setiap hari Selasa dan Jumat. Dhammasekha Saddhaphala memiliki potensi yang cukup baik karena berdiri ditengah basis komunitas umat Buddha. Namun sebagai suatu lembaga pendidikan nonformal kehadiran Dhammasekha dalam praktiknya mengalami berbagai problem. Berdasarkan hasil wawancara tanggal 19 Februari 2018 dengan Bapak Sariyono selaku mantan guru di Dhamamsekha, masalah yang intern terjadi cukup urgen terkait manajemen, ketidakefektifan struktur organisasi, budaya organsisasi, komitmen sumber daya manusia dan komunikasi yang lemah.

Permasalahan intern dan tantangan perlu dikelola serta dibutuhkan strategi untuk mengatasi agar mutu Dhammasekha menjadi baik dan semakin diminati oleh umat Buddha. Secara istilah mutu menurut Nasution (2004:15) adalah "Kualitas memenuhi atau melebihi harapan pelanggan" . Dengan demikian mutu adalah tingkat kualitas yang telah memenuhi atau bahkan dapat melebihi dari yang diharapkan.

Dhammasekha sebagai suatu lembaga pendidikan Buddhis yang mampu menjadi alternatif bagi masyarakat Buddha untuk mendapatkan pendidikan diluar pendidikan formal. Sebagai lembaga pendidikan agama Buddha yang mewadahi peserta didik Buddhis, perlu adanya strategi bagi Dhammasekha untuk mampu bersaing. Manajemen puncak pada organisasi Dhammasekha tentu telah menetapkan visi, misi dan pilihan strategi namun strategi yang dirancang bagus belum tentu berhasil hingga tahap implementasi maupun evaluasi atau bahkan belum membuat perbedaan nyata di lingkup masyarakat Buddha.

Manajemen strategi membantu Dhammasekha untuk menentukan arah agar dapat mewujudkan tujuan pendidikan dan memfasilitasi generasi muda untuk semangat belajar. Buddha juga bersabda arti penting belajar dalam kehidupan manusia. "Orang yang tidak mau belajar akan menjadi tua seperti sapi; dagingnya bertambah tetapi kebijaksanaannya tidak berkembang" (Dhp. 152). Hal ini dimaksudkan agar seseorang maupun organisasi tidak berhenti belajar sehingga tidak hanya sekedar eksis namun juga berinovasi. 
Peneliti tertarik untuk mengkaji formulasi dan implementasi manajemen di Dhammasekha Saddhapala Jaya yang berimbas pada mutu Pendidikan Agama Buddha. Manajemen strategik Dhammasekha digunakan untuk memantau potensi, kelemahan, peluang serta tantangan bagi mutu Dhammasekha sebagai suatu organisasi Buddhis dalam mencapai tujuan yang efektif dan efisien. Berdasarkan masalah yang telah disampaikan, peneliti tertarik untuk menggali potensi peluang dan kekuatan Dhammasekha serta mengidentifikasi ancaman dan kelemahan Dhammasekha agar menjadi bahan kebijakan dalam pengambilan keputusan pimpinan guna meningkatkan mutu Dhammasekha.

\section{LANDASAN TEORI MANAJEMEN STRATEGI}

Manajemen menurut Daft (2013:6) adalah pencapaian tujuan-tujuan organisasional secara efektif dan efisien melalui perencanaan, pengelolaan, kepemimpinan, dan pengendalian sumber daya organisasional. Definisi ini memiliki dua pemikiran penting : (1) keempat fungsi perencanaan, pengelolaan, kepemimpinan, dan pengendalian. (2) pencapaian tujuan-tujuan organisasional secara efektif dan efisien. Kreitner\&Kinicki (2014:16) menjelaskan bahwa manajemen merupakan proses bekerja dengan dan melalui orang lain untuk mencapai tujuan organisasi secara efisien dan etis di tengah perubahan yang konstan

Manajemen menurut Terry (2012:9) mencakup kegiatan untuk mencapai tujuan, dilakukan oleh individu-individu yang menyumbangkan upayyanya yang terbaik melalui tindakan-tindakan yang telah ditetapkan. Hal tersebut meliputi pengetahuan tentang apa yang harus mereka lakukan, menetapkan cara melakukan, memahami bagaimana melakukan dan mengukur efektivitas usaha. Selanjutnya perlu menetapkan dan memelihara pola suatu kondisi lingkungan yang memberikan respon serta pengendaliannya. Sedangkan Lee (2010) menyatakan manajemen adalah seni dan ilmu perencanaan

pengorganisasian,penyusunan,pengarahan dan pengawasan daripada sumberdaya manusia untuk mencapai tujuan yang telah ditetapkan. Berdasarkan pendapat ahli terkait definisi manajemen maka untuk penelitian istilah manajemen dapat diartikan sebagai suatu kegiatan organisasi yang meliputi perencanaan, pelaksanaan dan juga evaluasi untuk mencapai tujuan secara efektif dan efisien.

Kata 'strategi' berasal dari bahasa Yunani "strategos" yang berarti jenderal atau panglima, sehingga strategi diartikan sebagai ilmu kejenderalan atau ilmu kepanglimaan (Gulo, 2008). Strategi dalam pengertian kemiliteran ini berarti cara penggunaan seluruh kekuatan militer untuk mencapai tujuan perang. Strategi menurut Husein (2001) didefenisikan sebagai suatu proses penentuan rencana para pemimpin puncak yang berfokus pada tujuan jangka panjang organisasi disertai penyusunan suatu cara atau upaya bagaimana agar tujuan tersebut dapat dicapai.

Tim Pengembang Ilmu Pendidikan FIP UPI (2007), menguraikan apa yang dimaksud dengan strategi merupakan pola umum rentetan kegiatan yang harus dilakukan untuk mencapai tujuan tertentu. Dikatakan pola umum, sebab suatu strategi pada hakekatnya belum mengarah kepada hal-hal yang bersifat praktis, suatu strategi masih berupa rencana atau gambaran menyeluruh. Sedangkan, untuk mencapai tujuan, memang strategi disusun untuk tujuan tertentu. Tidak ada suatu strategi, tanpa adanya tujuan yang harus dicapai. Strategi dapat digunakan dalam berrbagai cara atau situasi. Sedangkan menurut Mintzberg (dalam Pella, 2016:13) strategi bisa berarti refleksi dalam kurun waktu tertentu. Strategi bisa berarti refleksi atas posisi organisasi atau perspektif visi arah tujuan masa depan organisasi. Berdasarkan pendapat diatas maka dapat disimpulkan bahwa strategi adalah pola atau penentuan proses dan kegiatan yang disusun untuk mencapai tujuan organisasi.

Manajemen strategi menurut Glueck (1988) adalah serangkaian keputusan-keputusan dan tindakan-tindakan manajerial yang mengarah pada penyusunan strategi-strategi efektif untuk mencapai tujuan perusahaan. Manajemen strategi adalah seni dan pengetahuan dalam merumuskan, mengimplementasikan, serta mengevaluasi keputusan-keputusan lintas fungsional yang memungkinkan sebuah organisasi untuk mencapai tujuan (David, 2011:6). Manajemen strategis berfokus pada proses penetapan tujuan organisasi, pengembangan kebijakan dan perencanaan untuk mencapai sasaran, serta mengalokasikan sumber daya untuk menerapkan kebijakan dan merencanakan pencapaian tujuan organisasi.

Manajemen strategik menurut Pella (2016:21) memungkinkan organisasi beranjak dari posisi saat ini mencapai posisi yang diimpikan di masa depan. Pella juga menyatakan bahwa manajemen strategik memiliki tiga langkah utama yakni analisis strategi, pengembangan strategi dan implementasi strategi . Sedangkan Gitosudarmo (2012:12) memaknai manajemen strategis sebagai manajemen yang bijak serta tidak keliru sehingga keputusan yang diambil harus dijalur yang benar untuk mencapai keberhasilan. Secara ringkas Daft 
(2013:248) menuliskan bahwa manajemen strategis merupakan serangkaian keputusan dan tindakan yang digunakan untuk merumuskan dan melaksanakan strategi yang memungkinkan kesesuaian sangat kompetitif antara perusahaan dengan lingkungannya sehingga dapat mencapai tujuan perusahaan. Berdasarkan pendapat beberapa ahli diatas maka dapat disimpulkan bahwa manajemen strategik adalah suatu rangkaian kegiatan pembuatan, penerapan dan evaluasi keputusan-keputusan strategis antar fungsi-fungsi yang memungkinkan untuk mencapai tujuan organisasi yang diharapkan.

\section{a. Tahapan Manajemen Strategik}

David (2011) menjelaskan bahwa proses manajemen strategis terdiri dari tiga tahapan, yaitu, memformulasikan strategi, mengimplementasikan strategi dan mengevaluasi strategi.

1) Tahap memformulasikan strategi antara lain menetapkan visi dan misi, mengidentifikasi peluang dan tantangan yang dihadapi organisasi dari sudut pandang eksternal, menetapkan kelemahan dan keunggulan yang dimiliki organisasi dari sudut pandang internal, menyusun rencana jangka panjang, membuat strategi-strategi alternatif dan memilih strategi tertentu yang akan dicapai.

2) Tahap mengimplementasikan strategi memerlukan suatu keputusan dari pihak yang berwenang dalam mengambil keputusan untuk menetapkan tujuan tahunan, membuat kebijakan, memotivasi pegawai, dan mengalokasikan sumber daya yang dimiliki sehingga strategi yang sudah diformulasikan dapat dilaksanakan. Pada tahap ini dilakukan pengembangan strategi pendukung budaya, merencanakan struktur organisasi yang efektif, mengatur ulang usaha pemasaran yang dilakukan, mempersiapkan budget, mengembangkan dan utilisasi sistem informasi serta menghubungkan kompensasi karyawan terhadap kinerja organisasi. Mengimplementasikan strategi sering disebut sebagai "action stage" dari manajemen strategis. Pengimplementasian strategi memiliki maksud memobilisasi para pegawai dan manajer untuk menterjemahkan strategi yang sudah diformulasikan menjadi aksi.

3) Tahap mengevaluasi strategi adalah tahap terakhir dalam manajemen strategis. Para manajer sangat perlu untuk mengetahui ketika ada strategi yang sudah diformulasikan tidak berjalan dengan baik. Evaluasi strategi memiliki tiga aktifitas yang fundamental, yaitu mereview faktor-faktor internal dan eksternal yang menjadi dasar untuk strategi saat ini, mengukur performa dan mengambil langkah korektif.

Hal ini sedikit berbeda dengan pendapat Wheelen dan Hunger (dalam Solihin, 2009:83) menjelaskan kegiatan manajemen strategi mencakup enviromental scanning sebagai suatu kegiatan monitoring, pengevaluasian, serta penyebaran infirmasi yang berasal dari lingkungan internal maupun eksternal perusahaan kepada personel kunci di dalam perusahaan. Setelah itu, maka masuk pada tahap perumusan strategi, implementasi serta evaluasi dan pengendalian. Namun dapat dipahami bahwa esensi utama terdiri dari proses formulasi, implementasi dan evaluasi.

\section{b. Tujuan Manajemen Strategi}

Suwandiyanto (2010:02) menyatakan bahwa terdapat empat tujuan manajemen strategi, yaitu:

a. Memberikan arah pencapaian tujuan organisasi/perusahaan. Dalam hal ini, manajer strategi harus mampu menunjukkan kepada semua pihak kemana arah tujuan organisasi/perusahaan. Karena, arah yang jelas akan dapat dijadikan landasan untuk pengendalian dan mengevaluasi keberhasilan.

b. Membantu memikirkan kepentingan berbagai pihak. Organisasi/perusahaan harus mempertemukan kebutuhan berbagai pihak, pemasok, karyawan, pemegang saham, pihak perbankan, dan masyarakat luas lainnya yang memegang peranan terhadap sukses atau gagalnya perusahaan.

c. Mengantisipasi setiap perubahan kembali secara merata. Manajemen strategi memungkinkan eksekutif puncak untuk mengantisipasi perubahan dan menyiapkan pedoman dan pengendalian, sehingga dapat memperluas kerangka waktu/berpikir mereka secara perspektif dan memahami kontribusi yang baik untuk hari ini dan hari esok.

d. Berhubungan dengan efisiensi dan efektivitas. Tanggung jawab seorang manajer bukan hanya mengkonsentrasikan terhadap kemampuan atas kepentingan efisiensi, akan tetapi hendaknya juga mempunyai perhatian yang serius agar bekerja keras melakukan sesuatu secara lebih baik dan efektif. 


\section{Mutu Dhammasekha}

Menurut Juran (1998), kualitas adalah kesesuaian untuk penggunaan (fitness for use), ini berarti bahwa suatu produk atau jasa hendaklah sesuai dengan apa yang diperlukan atau diharapkan oleh pengguna, lebih jauh Juran mengemukakan lima dimensi kualitas yaitu : 1 . Rancangan (design), sebagai spesifikasi produk 2. Kesesuaian (conformance), yakni kesesuaian antara maksud desain dengan penyampaian produk aktual 3. Ketersediaan (availability), mencakup aspek kedapatdipercayaan, serta ketahanan, dan produk itu tersedia bagi konsumen untuk digunakan 4. Keamanan (safety), aman dan tidak membahayakan konsumen 5. Guna praktis (field use), kegunaan praktis yang dapat dimanfaatkan pada penggunaannya oleh konsumen.

Mutu merupakan konsep yang terus mengalam perkembangan dalam pemaknaanya, menurut Garvin (1994) perspektif tentang konsep mutu mengalami evolusi sebagai berikut, ada lima alternatif perspektif kualitas yang biasa digunakan. Tokoh lain yang mengembangkan manajemen kualitas adalah Edward Deming. Menurut Deming (1982) meskipun kualitas mencakup kesesuaian atribut produk dengan tuntutan konsumen, namun kualitas harus lebih dari itu.

Dhammasekha merupakan lembaga pendidikan agama Buddha yang berada dibawah naungan Kementerian Agama Direktur Jenderal Bimbingan Masyarakat Buddha. Berdasarkan Surat Keputusan Direktur Jenderal Bimbingan Masyarakat Buddha Nomor 485 Tahun 2011 tentang Dhammasekha telah disampaikan bahwa Dhamma Sekha bertujuan membentuk manusia yang memiliki kecakapan hidup, keteramipan fungsional, sikap dan kepribadian profesional, dan mengembangkan jiwa wirausaha yang mandiri serta kompetensi untuk bekerja dalam bidang tertentu dan atau melanjutkan pendidikan ke jenjang yang lebih tinggi dalam rangka mewujudkan tujuan pendidikan nasional. Dhamma Sekha memberikan bekal kemampuan dasar sebagai perluasan dan peningkatan pengetahuan, agama dan keterampilan yang bermanfaat bagi siswa untuk mengembangkan kehidupannya sebagai umat Buddha, anggota masyarakat, warga negara dan sesuai dengan tingkat perkembangannya serta mempersiapkan mereka untuk hidup dalam masyarakat.

Berdasarkan Surat Keputusan Ditjen Bimas Buddha Nomor 485 Tahun 2011 tentang Dhammasekha Pasal 1 ayat 1, Dhammasekha secara umum merupakan salah satu bentuk Pendidikan Keagamaan Buddha (nonformal) yang diselenggarakan oleh Yayasan Pendidikan
Agama dan Keagamaan Buddha. Lebih lanjut, dalam Peraturan Menteri Agama Nomor 39 Tahun 2014 Pasal 4 dijelaskan bahwa pendidikan keagamaan Buddha nonformal disebut pendidikan Dhammasekha yang menyelenggarakan pendidikan ilmu-ilmu yang bersumber dari ajaran Buddha pada jenjang pendidikan anak usia dini, pendidikan dasar, dan pendidikan menengah, yang diselenggaran oleh pemerintah dan/atau masyarakat.

Suderadjat (2005: 17) berpendapat bahwa pendidikan yang bermutu adalah pendidikan yang mampu menghasilkan lulusan yang memiliki kemampuan atau kompotensi, baik kompetensi akademik maupun kompetensi kejuruan, yang dilandasi oleh kompetensi personal dan sosial, serta nilai-nilai akhlak mulia, yang keseluruhannya merupakan kecakapan hidup (life skill), lebih lanjut Sudradjat megemukakan pendidikan bermutu adalah pendidikan yang mampu menghasilkan manusia seutuhnya (manusia paripurna) atau manusia dengan pribadi yang integral (integrated personality) yaitu mereka yang mampu mengintegralkan iman, ilmu, dan amal.

Usman (2013 : 411) mengemukakan 13 (tiga) belas karakteristik yang dimiliki oleh mutu pendidikan yaitu:

a. Kinerja (performa) yakni berkaitan dengan aspek fungsional sekolah meliputi : kinerja guru dalam mengajar baik dalam memberikan penjelasan meyakinkan, sehat dan rajin mengajar, dan menyiapkan bahan pelajaran lengkap, pelayanan administratif dan edukatif sekolah baik dengan kinerja yang baik setelah menjadi sekolah favorit.

b. Waktu wajar (timelines) yakni sesuai dengan waktu yang wajar meliputi memulai dan mengakhiri pelajaran tepat waktu, waktu ulangan tepat.

c. Handal (reliability) yakni usia pelayanan bertahan lama. Meliputi pelayanan prima yang diberikan sekolah bertahan lama dari tahun ke tahun, mutu sekolah tetap bertahan dan cenderung meningkat dari tahun ke tahun.

d. Data tahan (durability) yakni tahan banting, misalnya meskipun krisis moneter, sekolah masih tetap bertahan

e. Indah (aesteties) misalnya eksterior dan interior sekolah ditata menarik, guru membuat media-media pendidikan yang menarik.

f. Hubungan manusiawi (personal interface) yakni menunjung tinggi nilai-nilai moral dan profesionalisme. Misalnya warga sekolah saling menghormati, demokrasi, dan menghargai profesionalisme. 
g. Mudah penggunaanya (easy of use) yakni sarana dan prasarana dipakai. Misalnya aturan-aturan sekolah mudah diterapkan, buku-buku perpustakaan mudah dipinjam di kembalikan tepat waktu.

h. Bentuk khusus (feature) yakni keuggulan tertentu misalnya sekolah unggul dalam hal penguasaan teknologi informasi (komputerisasi).

i. Standar tertentu (comformence to specification) yakni memenuhi standar tertentu. Misalnya sekolah tetlah memenuhi standar pelayanan minimal.

j. Konsistensi (concistency) yakni keajengan, konstan dan stabil, misalnya mutu sekolah tidak menurun dari dulu hingga sekarang, warga sekolah konsisten dengan perkataanya.

k. Seragam (uniformity) yakni tanpa variasi, tidak tercampur. Misalnya sekolah melaksanakan aturan, tidak pandang bulu, seragam dal berpakaian.

1. Mampu melayani (serviceability) yakni mampu memberikan pelayanan prima. Misalnya sekolah menyediakan kotak saran dan saran-saran yang masuk mampu dipenuhi dengan baik sehingga pelanggan merasa puas.

m. Ketepatan (acuracy) yakni ketepatan dalam pelayanan misalnya sekolah mampu memberikan pelayanan sesuai dengan yang diinginkan pelanggan sekolah.

Pengertian mutu atau kualitas Dhammasekhaberarti dapat diartikan sebagai kesesuaian Dhammasekha dalam mewujudkan harapan pengguna jasa pendidikan Dhammasekha

\section{METODE PENELITIAN}

Williams (dalam Moleong, 2014:5) menulis bahwa, "Penelitian kualitatif adalah pengumpulan data pada suatu latar alamiah, dengan menggunakan metode alamiah, dan dilakukan oleh orang atau peneliti yang tertarik secara alamiah".

Sudaryono (2017:88) menjelaskan penelitian studi kasus dan lapangan adalah penelitian dengan karakteristik masalah yang berkaitan dengan latar belakang dan kondisi saat ini dari subjek yang diteliti serta interaksinya dengan lingkungan.

Berdasarkan pendapat di atas peneliti menganggap bahwa, metode studi kasus tepat untuk mengungkap tentang fokus pada penelitian ini. Pendekatan studi kasus ini dimaksudkan dalam melakukan penelitian, peneliti memusatkan perhatian tentang manajemen strategik dalam pengembangan mutu Dhamma Sekha Saddhapala Jaya Kabupaten Temanggung. Pengamatan ini dilakukan secara terus menerus sampai dapat menjawab fokus penelitian. Pemilihan subjek penelitian ini menggunakan teknik purposive sampling. Dengan alasan peneliti membuhkan data dari informan yang sangat mengetahui tentang Dhammasekha Saddhapala Jaya.. Analisis data melalui reduksi data, penyajian data dan penarikan kesimpulan. Keabasahan data menggunakan teknik trianggulasi.

\section{HASIL PENELITIAN DAN PEMBAHASAN}

Berdasarkan data dari web resmi Kecamatan Kaloran, Wilayah desa Getas termasuk dataran tinggi dengan ketinggian \pm 700 sd $1200 \mathrm{~m}$ diatas permukaan laut dengan suhu rata-rata 23 sd $26{ }^{\circ} \mathrm{C}$ Letak topografi tanahnya perbukitan, dengan luas lahan persawahan dengan irigasi setengah teknis seluas $49 \mathrm{Ha}$, tadah hujan $30 \mathrm{Ha}$, serta lainnya merupakan lahan pertanian kering dan pemukiman. Sebagian besar masyarakat bekerja sebagai petani untuk lahan pertanian dan perkebunan.

Lokasi Gedung Dhammasekha Saddhapala Jaya tepat berada di Dusun KrecekKusala, Desa Getas, Kecamatan Kaloran KAbupaten Temanggung. Lokasi Gedung Dhammasekha Saddhapala Jaya berada di bawah jalan utama dan bersebelahan dengan lapangan. Selain itu Gedung Dhammasekha Saddhapala Jaya berada di lingkungan pedesaan dan berdekatan dengan beberapa rumah umat Buddha Dusun Krecek.

Dhammasekha Saddhapala Jaya memiliki lahan seluas $7000 \mathrm{~m} 2$ dan berada di samping Vihara Dhammasarana. Beberapa ruangan yang tersedia di Dhammasekha Saddhapala Jaya meliputi empat ruang kelas, dua kamar mandi dan dapur. Fasilitas lain yang tersedia dan mendukung kelengkapan sarana prasarana Dhammasekha adalah ruang perpustakaan, playground indoor serta ruang kesehatan siswa. Ruang kelas digunakan untuk kegiatan pembelajaran teori sedangkan kegiatan seni dan olahraga dilakukan di pendopo atau aula Dhammasekha yang diberi nama Pendopo Ngudi Mulyo.

Dhammasekha sebagai salah satu lembaga pendidikan di Desa Getas. Desa Getas merupakan salah satu desa yang ada di Kecamatan Kaloran, Temanggung dengan luas wilayah 815 hektar berbatasan Desa Kalimanggis disebelah utara, sebelah selatan berbatsan Desa Kebunangung, Kecamatan Sumowono, sebelah barat berbatasan Desa Tleter dan sebelah timur berbatasan Desa 
Tlogowungu. Desa Getas secara administratif terbagi menjadi 9 dusun yaitu: Dusun Getas, Nglarangan, Kemiri, Cendono, Banyuurip, Porot, Pringapus dan Krecek. Jarak Desa Getas menuju kecamatan kurang lebih berjarak empat kilometer sedangkan untuk jarak menuju Kabupaten Temanggung kurang lebih berkisar pada $19 \mathrm{Km}$.

\section{Formulasi strategi Dhammasekha}

Formulasi strategi sebagai dasar dalam manajemen strategi dilakukan dengan asesmen lingkungan yang terdapat di Dhammasekha Saddhapala Jaya terlebih dahulu. Menurut David (2011) Tahap memformulasikan strategi antara lain menetapkan visi dan misi, mengidentifikasi peluang dan tantangan yang dihadapi organisasi dari sudut pandang eksternal, menetapkan kelemahan dan keunggulan yang dimiliki organisasi dari sudut pandang internalPengamatan terhadap lingkungan ini terdiri dari dua aspek yaitu dari lingkungan internal dan juga lingkungan ekternal. Pengamatan ini dapat dilakukan dengan menggunakan analisis SWOT. Melalui analisis SWOT maka dapat diidentifikasi kekuatan (strength), kelemahan (weaknes), peluang (opportunity) dan tantangan (threat). Keseluruhan aspek ini akan menjadi pertimbangan bagi organisasi untuk menyusun suatu strategi organisasi.

\section{a. Kekuatan Dhammasekha}

Hasil asesmen lingkungan internal Dhammasekha Saddhapala Jaya berupa kekuatan (strength) yang meliputi:

1) Jumlah guru

Guru dan pegawai Dhammasekha berjumlah sembilan orang. Satu orang laki-laki dan delapan orang perempuan. Seluruh guru dan pegawai beragama Buddha. Dua orang guru merupakan sarjana pendidikan sekolah dasar sedangkan empat orang lain sarjana agama Buddha. Satu orang guru saat ini sedang dalam masa pendidikan S1 pendidikan guru PAUD dan dua orang guru wali kelas berpendidikan terakhir SMA.

Jumlah pendidik Dhammasekha juga dinyatakan oleh Bapak Parnu dalam wawancara sebagai berikut:

"Guru sejumlah sembilan itu masingmasing punya bidang tertentu. Jadi Bahasa Indonesia ada, Bahasa Inggrisnya ada, kebetulan disini gurunya yang Sarjana Pendidikan ada dua. Kalau selainnya ya S.Pd.B dan SMA. Memang untuk sarjana agama Buddha yang masih menganggur saya tarik kesini meskipun honornya tidak mencukupi untuk kebutuhan tapi minimal ya ada untuk ikatan. Sarjana pendidikan yang dua PGSD jadi sudah terbiasa untuk jadi guru kelas. Jadi yang mungkin perlu pelatihan yang lain".

Pernyataan ini diperkuat oleh Ibu Woro Inarsih yang mengatakan bahwa "gurunya disini ada sembilan mbak, yang dua itu memang PGSD terus kalau yang empat itu agama dan sisanya masih SMA tapi ada satu orang yang sekarang masa pendidikan di PGPAUD".

Guru Dhammasekha Saddhapala Jaya sudah mencukupi untuk kriteria kuantitas.. Masing-masing guru memiliki tanggung jawab sebagai wali kelas. Para guru mengajar kelas satu hingga kelas enam sekolah dasar dengan kemampuan di bidang-bidang tertentu. Jumlah guru yang memenuhi jumlah kelas tentu menjadi kekuatan tersendiri bagi efektifitas pembelajaran di Dhammasekha Saddhapala Jaya. Jumlah guru yang seimbang dengan jumlah siswa memungkinkan pembelajaran dan pendidikan yang efektif terlebih lagi apabila guru memiliki kemampuan di berbagai bidang yang dibutuhkan siswa.

\section{2) Keunggulan di bidang seni dan budaya}

Bimbingan belajar di Dhammasekha Saddhapala Jaya tidak hanya berfokus pada ilmu pengetahuan dan agama saja melainkan juga keterampilan, seni dan budaya. Hal ini seperti yang dinyatakan oleh Ibu Woro "Disini anak-anak diajari keterampilan, kalau waktunya SKB anakanak diajak diajak bikin karya-karya seperti taplak dari sedotan, kesenian dari kain flanel". Terkait hasil karya keterampilan siswa, Ibu Woro juga menjelaskan bahwa sebagian karya disimpan di Dhammasekha dan sebagian besar dibawa pulang oleh siswa untuk ditunjukkan pada orang tua.

Bapak Parnu menambahkan "Skill anak yang ditonjolkan seni dan budaya. Biasanya kalau ada Dharmasanti di daerah-daerah. Biasanya ada sedikit sumbangan dari panitia untuk beli bedak kalau mereka tampil". Ibu Rubiyanti selaku guru dan admin di Dhammasekha menambahkan bahwa di Dhammasekha memiliki andalan di bidang seni khususnya seni tari dan alat musik angklung. Berdasarkan hasil dokumentasi diketahui para siswi sedang menunggu giliran untuk tampil dalam suatu event seni dan budaya. Para siswa dengan sabar menanti hingga waktu tiba untuk tampil. Balutan baju tradisional dan riasan sanggul menambah keanggunan para siswi. Hal ini menandakan kesiapan para siswi. 


\section{3) Sarana dan Prasarana yang Memadai}

Sarana prasarana merupakan bagian penting dalam suatu pendidikan. Sarana dan prasarana yang memadai tentu akan mendukung pembelajaran yang efektif dan efisien. Hal ini disampaikan oleh Ibu Walmiyati "disini anak-anak diajak bermain dan belajar supaya betah dan senang. Kalau anak senang, belajarnya juga jadi semangat". Selain itu Ibu Woro juga menjelaskan bahwa

Dhammasekha Saddhapala Jaya memiliki ruang yang digunakan untuk proses pembelajaran dan juga fasilitas bermain yang aman dan sesuai dengan kebutuhan anak. Keamanan menajdi bagian yang diperhatikan oleh para guru dimana pada area bermain diberi alas yang lunak agar menghindari cidera ketika anak bermain. Selain itu, arena bermain anak ditata secara rapi dan colourful. Fasilitas ruang bermain atau playground di dalam ruangan juga terdapat di Dhammasekha Saddhapala Jaya .

Perpustakaan merupakan salah satu fasilitas yang sangat berpengaruh terhadap pengetahuan para siswa. Para siswa Dhammasekha diberi kesempatan untuk membaca secara mandiri maupun dengan bimbingan guru di perpustakaan. Ruang perpustakaan Dhammasekha juga sangat rapi dan memiliki bahan bacaan yang bervariasi bidang ilmunya. Anak-anak dapat menggunakan ruang perpusatakan dan membaca buku disaat jam menunggu waktu Dhammasekha dimulai.

Fasilitas lain yang mendukung semangat para siswa yaitu terdapat mobil inventaris Dhammasekha yang berguna untuk antar jemput. Mobil yang dimiliki oleh Dhammasekha berjumlah dua unit. Lokasi Dhammasekha yang cukup jauh dari tempat tinggal para siswa dapat diatasi dengan adanya fasilitas antar jemput yang disediakan oleh pihak Dhammasekha. Hal ini sesuai dengan pernyataan Bapak Parnu "Nah untungnya disini ada dua mobil antar jemput, kan siswanya jauh-jauh jadi bisa diambil dengan mobil itu".

4) Bhikkhu Dhammakaro sebagai Pembina

Dhammasekha Saddhapala Jaya merupakan Dhammasekha yang berada di bawah naungan Yayasan Saddhapala Jaya. Dhammasekha ini dibina langsung oleh Bhikkhu Dhammakaro yang merupakan anggota Sangha Theravada Indonesia. Hal ini sesuai dengan pernyataan Bapak Parnu bahwa "Sangha yang menaungi
Dhammasekha ini adalah Sangha Theravada Indonesia dan kebetulan disini untuk pembina yayasan adalah Bhante Dhammakaro, beliau sering kesini pasti kesini minimal tiga bulan sekali". Ibu Walmiyati juga menambahkan bahwa "disini ada bhantenya, bhante Dhammakaro yang membina".

Memiliki sosok seorang bhikkhu sebagai pembina tentu akan mengondisikan citra positif dilingkungan masyarakat khususnya umat Buddha. Seorang bhikkhu adalah tokoh yang menjalankan praktik moralitas sehingga umat lebih mudah mengenal dan yakin terhadap binaan Bhikkhu. Bhikkhu Dhammakaro Mahathera juga secara kontinyu mendampingi perkembangan Dhammasekha.

\section{b. Kelemahan Dhammasekha}

Dhammasekha sebagai suatu lembaga pendidikan yang baru berdiri tiga tahun sejak diresmikan tentu memiliki kelemahan-kelemahan. Berikut adalah kelemahan Dhammasekha Saddhapala Jaya yang menjadi kelemahan:

1) Minimnya Sumber Dana

Sumber dana yang digunakan sebagai biaya operasional Dhammasekha diperoleh dari dana sukarela umat Buddha yang peduli terhadap pendidikan. Hal ini sesuai dengan pernyataan Ibu Rubiyanti "Yayasan selama ini dananya diperoleh ada dari donatur yang dari Jakarta, mereka berdana. Sama ada juga umat yang peduli dengan pendidikan".

Pembiayaan operasional Dhammasekha yang cukup besar belum seimbang dengan pendapatan yang diperoleh Dhammasekha. Hal ini disebabkan karena sejauh ini Dhammasekha masih mengandalkan sumbangan sukarela dari umat dan tidak menetapkan biaya pendidikan yang dibebankan pada siswa. Hal ini disampaikan oleh Bapak Parnu sebagai berikut:

"Kalau saya belum berani menekankan 'eh iuran sekian' begitu, tapi yang saya tawarkan kan ya hanya 'mari kita kan melakukan kebajikan' jadi ya hanya bantuan sukarela jadi itu tiap bulan sukarela, jadi ya ada yang sepuluh ribu, ada lima belas ribu, bahkan ada juga yang dua ribu, ya begitulah".

Selain itu Dhammasekha juga masih sangat kekurangan biaya karena terbatasnya jumlah donatur yang memberikan dana besar. Sehingga pengeluaran Dhammasekha lebih besar 
dibanding jumlah pemasukan yang seharusnya sehingga berpengaruh terhadap kegiatan Dhammasekha. Ibu Woro Inarsih juga menambahkan "Kalau kelemahan ya masih lingkup pendanaan, jadi kalau ingin mengembangkan kegiatan masih terbatas dengan dana". Ibu Rubiyanti juga menambahkan "Sejauh ini lebih besar pengeluaran daripada pemasukan sedangkan donatur kita kan masih terbatas".

\section{2) Implementasi Kurikulum Belum Optimal} Dhammasekha sebagai lembaga pendidikan yang baru berdiri masih kesulitan dalam menyusun kurikulum yang mampu menjawab harapan para pengguna. Kurikulum yang digunakan Dhammasekha masih berubahubah dan belum paten $\mathrm{Hal}$ ini terjadi karena masih menyesuaikan dengan kurikulum sekolah dasar dan dhammasekha dari Dirjen Bimas Buddha. Hal ini seperti pernyataan Bapak Parnu bahwa "Kurikulumnya sudah ada, tapi ya baru saja ada, karena belum ada satu tahun yang dari pusat. Karena baru saja kan dapatnya dari pusat. Kalau kemarin-kemarin ya anak-anak berkumpul ya hanya seperti di SD saja karena kurikulumnya kan belum ada". Ibu Rubiyanti menambahkan bahwa " ya sebenarnya sudah ada kurikulum tapi belum paten, masih menyesuaikan dengan sekolah dasar".

3) Lokasi Dhammasekha yang Jauh dan Motivasi Siswa yang Lemah

Beberapa siswa Dhammasekha Saddhapala Jaya memiliki semangat belajar dalam kategori lemah. Hal tersebut terjadi karena rumah yang cukup dan juah dari lokasi Dhammasekha. Hal ini sesuai dengan pernyataan Bapak Parnu bahwa "mereka (para siswa) yang tersebar dari beberapa vihara kesini pakai dua mobil antar jemput, meski ada yang sudah di jemput juga masih malas-malasan". Selain itu jam belajar yang dilakukan seusai siswa belajar di sekolah formal mengondisikan siswa kelelahan. Kegiatan sekolah formal yang sudah menyita waktu dan energi sehingga menyebabkan pembelajaran menjadi kurang efektif terlebih lagi karena lokasi Dhammasekha cukup jauh dari rumah beberapa siswa. Hal ini disampikan oleh Ibu Rubiyanti "mungkin dari segi waktu yang kurang bikin kurang efektif karena capek, apalagi anak-anak yang dari jauh". Ibu Walmiyanti juga menambahkan "Terkait ketepatan waktu siswa belajar ya kadang masih ada molornya, karena anak-anak kan dari jauh jadi butuh waktu untuk sampai disini. Kadang supirnya juga ada acara jadi menyelesaikan dulu".
4) Belum memiliki ijin operasional lembaga

Dhammasekha Saddhapala Jaya menghadapi masalah terkait pengurusan ijin operasional. Hal ini berakibat terhadap permasalahan terkait permohonan bantuan dana kepada Dirjen Bimas Buddha. Hal ini disampaikan oleh Bapak Parnu "Untuk mengurus ijin operasionalnya masih belum clear, nanti kalau sudah clear nah baru kami akan mengajukan bantuan dana ke pusat".

\section{c. Peluang Dhammasekha}

Dhammasekha Saddhapala Jaya memiliki beberapa peluang yang teridentifikasi dan memungkinkan Dhammasekha untuk berkembang dan mencapai tujuan. Salah satu peluang Dhammasekha Saddhapala Jaya yaitu memiliki donatur yang memberikan bantuan untuk pembangunan gedung serta menunjang kegiatankegiatan bermanfaat. Seperti pernyataan Bapak Parnu sebagai berikut:

"Ini Dhammasekha
pembangunannya murni dari donatur,
pembangunannya sama sekali tidak dapat
sepeserpun dari pemerintah. Jadi kalau ini
benar benar murni dari donatur. Jadi ini
swadaya umat Buddha, anak-anak yang
disini yang tergabung dalam yayasan ada
16 vihara, kita buat komunitas lalu kita
bentuk yayasan"
Peluang Dhammasekha terdapat pada
dukungan umat Buddha dari lingkungan yang tergabung dalam suatu yayasan. Yayasan yang tergabung dalam Yayasan Dhammasekha Saddhapala Jaya terdiri dari 16 vihara. Hal ini mengondisikan Dhammasekha Saddhapala Jaya tidak mengalami kesulitan mendapatkan siswa serta dukungan dari umat Buddha di Temanggung. Ibu Woro menyatakan "Krecek sini mayoritas Buddhis, Ndelen tetangga ini juga mayoritas Buddhis. Umat Buddha di daerah sini banyak".

\section{d. Ancaman Dhammasekha}

Ancaman lingkungan eksternal terhadap eksistensi Dhammasekha Saddhapala Jaya yang paling mencolok adalah berdirinya lembaga pendidikan lain yang juga berabasis agama. Lembaga pendidikan lain berada tidak jauh dari Dhammasekha Saddhapala Jaya ini lebih agresif dan kreatif sehingga memungkinkan siswa beralih pada pendidikan lain. Kecemasan ini disampaikan oleh Ibu Rubiyanti "Disini itu kayak Indonesia kecil, agama kan macam-macam jadi kalau anakanak tidak dibekali keyakinan kan nanti mudah pindah". Ibu Woro juga menambahkan "Tantangan beratnya satu, lingkungan, itu yang pertama dalam arti diluar komunitas kita. Karena 
ya ada saja pengaruh dari luar yang mungkin karena sering diajak, nah kalau di mereka kan sering dikasih apa gitu, lalu diberikan reward. Kalau disini ya sesekali juga ada tapi hanya khusus yang berprestasi”.

Bapak Parnu juga menjelaskan bahwa sistem pendidikan bimbingan belajar dari pusat pengembangan anak dari keyakinan lain lebih aktif. Kegiatannya disana seminggu tiga kali dan setiap kegiatannya diawali dengan doa lain sehingga para tokoh Buddhis cukup prihatin karena anak-anak jadi lebih terbiasa dengan doa yang bukan dari Buddha.

\section{Manajemen Strategi dalam Peningkatan Mutu Dhammasekha.}

Dhammasekha Saddhapala Jaya sangat peduli terhadap kebutuhan para pelanggan pendidikan. Menurut Green Wood (dalam Iskandar, 2017) dikatakan bahwa terdapat lima para pelanggan pendidikan. Salah satunya adalah orang tua siswa. Dhammasekha Saddhapa berupaya untuk memenuhi harapan dan kebutuhan para pengguna Dhammasekha dengan melakukan rapat dan evaluasi terhadap kinerja Dhamamsekha. Dhammasekha Saddhapala Jaya menerima kritik dan saran dari para pengguna yang diwadahi dalam suatu yayasan. Kegiatan rapat dan evaluasi kegiatan Dhammasekha setiap selapan sekali.

Ibu Woro juga menjelaskan "Biasanya sih kalau ada apa-apa kami selalu rembukan, jadi rapat intern rapat dengan guru-guru dan bersama. Keputusan tidak hanya dari ketua dhammasekha. Jadi setiap awal semester baru kita rapat dulu. Ketika rapat ada guru, ketua, yayasan dan Bhante Dhammakaro." Berdasarkan pernyataan Ibu Woro dapat dipahami bahwa Dhammasekha Saddhapala Jaya mengutamakan kepuasan pelanggan dan melakukan perbaikan terus menerus. Hal ini sesuai dengan pendapat Goetsch\&Davis (dalam Usman, 2013: 609) bahwa fokus pada kepuasan pelanggan dan perbaikan sistem secara terus menerus membantu mutu meningkat.

Para guru, ketua, pembina dan seluruh anggota yayasan turut serta mengawal Dhammasekha dalam meningkatkan mutu melalui komunikasi yang baik. Ketua Dhammasekha juga tidak menerapkan gaya kepemimpinan yang otoriter melainkan segala keputusan merupakan hasil dari musyawarah. Disini pemimpin Dhammasekha mengaplikasikan kepemimpinan yang demokratis sebagai upaya peningkatan mutu Dhammasekha. Pimpinan berusaha membangun kerja sama tim untuk menyatukan tujuan dan bijak dalam pengambilan keputusan sehingga meningkatkan komitmen jangka panjang sekalipun gaji atau upah guru belum sesuai. Meskipun nilai upah yang masih minim di angka Rp 400.000; namun para guru meyakini sebagai bentuk pengabdian dalam pengembangan pendidikan dan Buddha Dhamma.

Pendidikan dan pelatihan (Usman, 2013;610) merupakan faktor yang mendasar, dengan pendidikan dan pelatihan setiap guru dan staf tatat usaha akan meningkat keterampilan teknisnya. Salah satu loyalitas para guru dipengaruhi karena adanya kepedulian Dhammasekha terhadap keterlibatan dan pemberdayaan guru. Guru yang belum memenuhi persyaratan formal, didukung untuk melaksanakan pendidikan dan pelatih sebagai penunjang kelayakan sumber daya manusia Dhammasekha Saddhapala Jaya. Bapak Parnu menyatakan bahwa: "Sekarang gurunya ada yang sedang pendidikan PGPAUD namanya Santi Suryani. Nah ini ada pihak yayasan ada sedikit kita bantu dari yayasan untuk membantu SPP kuliah. Mungkin juga tidak cukup tapi kita ya hanya membantu supaya ada semangat. Lalu guru yang dudlunya masih SMP sekarang menempuh persamaan, yayasan juga membantu".

Dhammasekha Saddhapala Jaya memiliki visi yang secara tersirat berorientasi pada ilmu pengetahuan dan keagaaman. Hal ini dapat diketahui dari pernyataan Ibu Woro bahwa "pembelajaran yang terdapat pada Dhammasekha ini berbasis ilmu pengetahuan dan keagamaan". Selanjutnya Bapak Parnu menjelaskan sebagai berikut:

"Disini untuk bidang pendidikannya adalah seperti halnya kita mengelola SD tapi $60 \%$ adalah pendidikan Agama dan selain itu ada life skill, umum juga ada jadi ada matematika, bahasa Indonesia, IPA, IPS itu juga ada. Ini harapannya ada Dhammasekha, untuk supaya tidak mudah terpengaruh, yang kedua untuk meningkatkan skill anak dan pengetahuan anak ketika di SD mereka memiliki kelebihan dan nilai tambah".

Berdasarkan pernyataan Bapak Parnu dapat dipahami bahwa Dhammasekha didirikan dengan tujuan agar generasi muda 
Buddhis memiliki waktu yang padat untuk mengembangkan nilai positif. Para generasi muda terdidik dan diajarkan pengetahuan agama agar tidak mudah terkontaminasi dengan pengaruh lingkungan yang kurang baik bagi. Dhammasekha berupaya menanamkan keyakinan (saddha) terhadap para generasi muda melalui keteladanan dan implementasi budaya organisasi berciri Buddhis dengan harapan kemampuan intelektual siswa juga dilengkapi kemampuan spritual dan emosional.

Kualitas peserta didik yang tergabung di Dhammasekha Saddhapala Jaya berkembang dibidang seni dan pengetahuan setelah mengikuti bimbingan belajar di Dhammasekha. Hal ini dinyatakan oleh Bapak Ibu Woro "anak-anak dari sini, setelah ada Dhammasekha ini, anak yang sudah di SD sering ditunjuk untuk mengikuti kegiatan atau lomba-lomba yang mewakili sekolahnya, lombanya juga ada yang seni ada yang mata pelajaran". Bapak Parnu menambahkan "sebagian yang disini kan gabungan dari SD mana-mana, setelahnya belajar di Dhammasekha ya ada nilai lebihnya gitu, dari nilainya bisa kelihatan". Berdasarkan pernyataan Ibu Woro dan Bapak Parnu bahwa bimbingan belajar yang dilaksanakan di Dhammasekha meemberikan pengaruh baik terhadap prestasi siswa. Selain itu Henik sebagai siswa juga menjelaskan bahwa senang dapat kesempatan mengikuti kegiatan bimbingan belajar di Dhammasekha karena pembelajaran yang menyenangkan, dapat berkumpul dengan banyak teman dan membantu mengatasi kesulitan belajar yang dialami.

Dhammasekha Saddhapala Jaya dikenal baik oleh masyarakat sekitar. Perangkat desa dan umat Buddha sangat mendukung keberadaan Dhammasekha. Dhammasekha mampu membangun citra positif masyarakat sebagai lembaga pendidikan yang mampu memfasilitasi kebutuhan masyakarat Buddhis di sekitar. Hal ini dapat diketahui dari pernyataan Bapak Parnu bahwa "Pendirian Dhammasekha ini untungnya juga tidak terlalu sulit. Dalam jangka waktu satu bulan ijin pendirianya bisa keluar. Jadi ya kami mengupayakan semua syarat-syarat terpenuhi jadi ketika pengajuan, semuanya bisa berjalan"

Manajemen strategi Dhammasekha sebagai suatu organisasi dapat meninjau kembali berbagai kekuatan (streghts), kelemahan (weakness), peluang (opportunities) dan berbagai ancaman (threats). Dhammasekha Saddhapala Jaya menyadari adanya ancaman serta kelemahan yang setiap saat dapat mengahalangi keberhasilan lembaga Dhammasekha, namun Dhammasekha Saddhaphala juga memiliki berbagai potensi dan peluang untuk ditonjolkan sebagai kekuatan dalam membangun mutu pendidikan Dhammasekha Saddhapala Jaya sesuai harapan pengguna.

\section{SIMPULAN}

Dhammasekha Saddhapala Jaya sebagai suatu organisasi atau lembaga pendidikan memiliki tujuan untuk menanamkan keyakinan, moralitas dan meningkatkan kualitas sumber daya manusia. Manajemen strategi diawali dengan formulasi strategi Dhammasekha yakni dengan mengidentifikasi kekuatan, kelemahan, peluang dan ancaman Dhammasekha. Berdasarkan hasil penelitian dapat diketahui bahwa kekuatan Dhammasekha terdapat pada 1) ketersediaan dan profesionalitas guru; 2) keunggulan di bidang seni dan budaya; 3) sarana dan prasarana yang memadai meliputi gedung dan alat transportasi; 4) Bhikkhu sebagai pembina sehingga terdapat citra positif dari umat Buddha. Kelemahan Dhammasekha meliputi 1) sumber pembiayaan yang masih minim; 2) kurikulum yang belum sempurna, 3) lokasi Dhammasekha yang sulit, dan 4) motivasi siswa sebagian siswa yang masih lemah, 5) belum memiliki ijin operasional. Peluang Dhammasekha menjadi lembaga pendidikan pilihan umat Buddha Kabupaten Temanggung karena didukung oleh 16 Vihara sedangkan ancaman dari sisi eksternal yaitu terdapat lembaga pendidikan lain yang lebih aktif dan kreatif di dekat lokasi Dhammasekha. Implementasi strategi tertuang dalam struktur organisasi. Evaluasi strategi dilakukan kontinyu. Dhammasekha mempertahankan beberapa komponen mutu antara lain berfokus pada pelanggan, komitmen, kerjasama tim, perbaikan secara terus menerus, pendidikan dan pelatihan, serta melibatkan dan memberdayakan guru, tenaga pendidikan dan para stakeholder untuk bersama-sama meningkatkan mutu Dhammasekha Saddhapala Jaya.

\section{DAFTAR PUSTAKA}

Akdon. 2007. Strategic Management for Educational Management. Bandung: Alfabeta.

Daft, Richard L. 2013. New Era Management, 9th Ed. (trans: Tita Maria Kanita) Era Baru Manajemen Edisi 9-Buku 1. Jakarta: Salemba Empat.

David, F.R. 2011. Manajemen Strategis: Konsep. Edisi ketujuh. Jakarta: PT. Prenhallindo.

Deming, W. Edwards. 1982. Guide to Quality Control. Cambirdge: Massachussetts Institute Of Technology. 
Garvin. 1994. Kualitas Produk: Alat Strategi Yang Penting. Free Press

Gitosudarmo, Indriyo. 2012. Manajemen Strategis. Yogyakarta: BPFE-Yogyakarta.

Glueck, W.F., Jauch, L.R. 1988. Business Policy and Strategy Management. Singapore: McGraw Hill.

Gulo, W. 2008. Strategi Belajar Mengajar. Jakarta: Grasindo.

Juran, Joseph M. 1998. Juran's quality handbook 5th edition. New York: McGrawHill.

Lee, Oey Liang. 2010. Pengantar Manajemen. Jakarta: Salemba Empat.

Moleong, L. J. 2014. Metode Penelitian Kualitatif Edisi Revisi. Bandung: PT. Remaja Rosdakarya.

Pella, Darmin Ahmad. 2016. Problem Implementasi Strategi, Temukan dan Atasi Penyebab Kegagalan Implementasi Strategi di Organisasi Anda. Jakarta: Penerbit Aida Infini Maksima.

Rusniati. 2015. Pendidikan Nasional dan Tantangan Globalisasi: Kajian Kritis terhadap Pemikiran Al Malik Fajar. Aceh: Jurnal Ilmiah Didaktika Media Ilmiah Pendidikan dan Pengajaran. Vol 16, No 1 (diakses 02/02/18).

Solihin, 2009. Pengantar Manajemen. Jakarta: Penerbit Erlangga.

Sudaryono. 2017. Metodologi Penelitian. Jakarta: PT Raja Grafindo Persada.

Suderadjat, Hari. 2005. Manajemen Peningkatan Mutu Berbasis Sekolah; Peningkatan Mutu Pendidikan Melalui Implementasi KBK. Bandung: Cipta Lekas Garafika

Suwandiyanto, M. 2010. Manajemen Strategi dan Kebijakan Perusahaan. Bandung: Alfabeta.

Terry, George R. 2012. Guide to Manajemen. (trans: Smith) Prinsip-prinsip Manajemen Cetakan Kesebelas. Jakarta: PT Bumi Aksara.

Tim Pengembang Ilmu Pendidikan FIP UPI, Ilmu \& Aplikasi Pendidikan Bagian.2. (Imperial Bhakti Utama, 2007). Hal. 167. 